\title{
FROM THE EDITORS
}

The NALLD JOURNAL is changing. Beginning with Volume 19, there will be four issues in each volume. The new fourth issue, intended to be used as a reference, will include the membership list, sources of materials and equipment, IALL organizational news, and any other information of use to the JOURNAL'S readers. Jackie Tanner of Ceorgetown University, the chairman of the Publications Committee, has been appointed Editor of this reference issue and all suggestions and comments should be sent to her.

Articles in the three regular issues of the JOURNAL will concentrate on media in language instruction in five main subject areas: satellite television, computer assisted instruction, language laboratory management, video and its related materials and equipment, and audio and its related materials and equipment. There will also be some new features, including brief notices of projects of interest to other IALL members. If you are involved in such a project or program, please send a brief summary to the Editor. More information on new features will appear in Volume 19.

A new editorial structure for the JOURNAL is already being implemented. Appointments to an Editorial Board will be announced soon. Dale Lally will continue as Editor-in-Chief and all material for publication in Volume 19 should be sent to him. He will be assisted by Managing Editor Sharon Scinicariello of Muskingum College. She will work with the authors of articles and with the printer on the final editing of each issue. For help with the documentation style used in the JOURNAL, look for the new "Guidelines for Authors" in the next issue.

The position of Advertising Manager of the JOURNAL is open. A successful candidate must be able to solicit advertising by phone and correspondance, to help determine ad rates and create brochures, to work with the Editors to determine the placement of ads in each issue, and to work with the Treasurer of IALL in the billing of advertising. The Advertising Manager participates in IALL as a member of the Executive Council. Anyone interested in this position should apply to: President Roger Sanchez-Berroa, International Association for Learning Laboratories, 116 Fisk Hall, Wesleyan University, Middletown, CT 06457.

The NALLD JOURNAL exists to serve all IALL members. Please send your comments and suggestions to the editors. Because Dale Lally is abroad, the next issue will be edited by Jackie Tanner.

The NALLD JOURNAL (New Advances in Learning Laboratory Developments ISSN 0027-5905) is currently published three times annually (Fall, Winter, Spring/Summer) by the International Association of Learning Laboratories (IALL). Membership in the Association is open to anyone associated with or interested in furthering the effective use of media in all areas of instruction. Membership year begins on October 1 and includes a subscription to the JOURNAL.

Opinions expressed in signed articles are those of the authors. Although the JOURNAL editors attempt to screen advertising for integrity, all advertising remains the responsibility of the advertiser. Neither opinions expressed in the articles nor advertising carry IALL approval unless specifically adopted by the IALL Executive Board. The NALLD JOURNAL is indexed in the CURRENT INDEX OF JOURNALS IN EDUCATION and is cited LANGUACE AND LANCUAGE BEHAVIORAL ABSTRACTS.

RATES (Beginning with Volume 17): North America \$15; all other areas and institutions \$20; students $\$ 10$. Sustaining memberships \$100. Back Issues are $\$ 7$ each. This publication is available on microfilm from: University Microfilms International, 300 North Zeeb Road, Dept. P.R., Ann Arbor, MI 48106 or 30.32 Mortimer St., Dept. P.R., London WIN TRA England.

Dues, subscriptions, changes of address, and orders for back issues should be sent to the JOURNAL at the address indicated above. Payment is required in U.S. funds drawn on U.S. or Canadian banks. Make all checks payable to IALL.

Advertising queries should be sent to Iris Wingert, NALLD Advertising Manager, Instructional Media Resources, University of Maryland-Baltimore County, Catonsville, MD 21228.

POSTMASTER: Send Form 3579 to NALLD JOURNAL, Bingham Humanities 16, University of Louisville, KY 40292 . Third class postage paid at Louisville, Kentucky. Copyright 1983 by the International Association of Learning Laboratories. 